\title{
SYSTEMATIZACE NE-ŘIDIČSKÝCH ČINNOSTÍ ŘIDIČŮ AUTONOMNÍCH NÁKLADNÍCH VOZIDEL
}

\section{SYSTEMATIZATION OF NON-DRIVING ACTIVITIES OF DRIVERS OF AUTONOMOUS TRUCKS}

\author{
Libor Krejč́1 ${ }^{1}$ Štěpánka Doleželová1*
}

\begin{abstract}
Abstrakt
$V$ článku je navržený koncept katalogu systematizující tzv. ne-řidičské aktivity řidičů nákladních vozidel, které by mohli vykonávat s rozvojem automatizace silničních vozidel. V blízké budoucnosti se jedná především o částečně automatizovaný provoz bez plné automatizace, při kterém je stále nezbytné, aby řidič v prípadě potreby převzal ř́zení. Přesto trend automatizace provozu nákladních vozidel přinese řadu př́ležitostí, jak efektivně využít pracovní čas budoucích řidičů, který je v současnosti věnován primárně řizení. Autoři představují postupné kroky ke genezi, analýze a klasifikaci činností, které řidiči budou moci ve vozidle provádět v době, kdy aktivně vozidlo neřídí. Byly použity metody indukce souvislostí v podobě myšlenkových map, komparace, klasifikační a funkční analýzy a klasifikace. Katalog je zaměřen na dvě úrovně automatizace vozidel L3 a L4 dle normy SAE. Systematická struktura katalogu je založena na číselných kódech kategorizujících činnosti minimálně ve čtyřech úrovních. V článku jsou predstaveny skupiny činností: duševní tvưrčí činnost; komunikace; administrativa, fyzická činnost; vzdělávání; zábava a odpočinek. Součástí je také príklad části vyplněného katalogu. Na závěr jsou doporučeny další směry rozvoje navrženého konceptu katalogu. Katalog bude v budoucnu využit manažery dopravních firem pro tvorbu skladby práce svých zaměstnanců. Další uživatelé budou například ústřední orgány státní správy, vzdělávací instituce a další odborné organizace $v$ dopravě.
\end{abstract}

Klíčová slova autonomní vozidlo, nákladní doprava, katalog, ne-řidičské činnosti, klasifikace činností

Summary The article proposes a concept of a catalogue systematizing the so-called non-driving activities of truck drivers, which they could perform with the development of automation of road vehicles. In the near future, this is mainly a partially automated operation without full automation, in which it is still necessary for the driver to take control of the vehicle if necessary. Nevertheless, the trend of automation of truck operation will bring a number of opportunities to effectively use the working time of future drivers, which is currently devoted primarily to driving. The authors present step-by-step steps towards the genesis, analysis and classification of activities that drivers will be able to perform in a vehicle when they are not actively driving. Context induction methods in the form of mind maps, comparisons, classification and functional analysis and classification were used. The catalogue focuses on two levels of automation of L3 and L4 vehicles according to the SAE standard. The systematic structure of the catalogue is based on numerical codes categorizing activities on at least four levels. The article presents groups of activities: mental creative activity; communication; administration, physical activity; education; fun and relaxation. An example of a part of a completed catalogue is also included. Finally, other directions of development of the proposed catalogue concept are recommended. In the future, the catalogue will be used by managers of transport companies to create the composition of the work of their employees. Other users will be, for example, central state administration bodies, educational institutions and other professional organizations in transport.

Keywords autonomous vehicle, freight transport, catalogue, non-driving activities, classification of activities

1 Centrum dopravního výzkumu, Líšeňská 33a, 63600 Brno

* korespondenční autor: e-mail: stepanka.dolezelova@cdv.cz 


\section{1 ÚVOD}

Rozvoj automatizace vozidel je jedním ze základních trendů, který se projevuje v oblasti nákladní i osobní dopravy, společně s náhradou konvenčních pohonů (elektromobily, CNG, LNG, vodík) a zejména v osobní dopravě posunem od vlastnictví vozidel k jejich sdílení (mobilita jako služba), (např. Litman, 2020; Goodall, et al., 2017; Lazarus, et al., 2018). V nákladní dopravě je na pan-Evropské úrovni snaha o přesun od př́mé silniční dopravy ke kombinované dopravě, případně celkový modal shift směrem k železniční či vnitrozemské vodní přepravě (Evropská komise, 2011). V oblasti silniční nákladní dopravy je důležitým nástrojem pro zvýšení efektivity přeprav maximalizace využití povolené objemové a hmotnostní kapacity vozidel např. pomocí lepší organizace přeprav a vytěžování vozidel s využitím elektronických burz nákladů (Witkowski, 2018). Podle Taniguchiho et al. (2016) jsou důležité taktéž kroky k řešení nákladní dopravy ve městech, výstavba konsolidačních center a řešení distribuce poslední míle.

Jednotlivé úrovně automatizace vozidel jsou standardizovány podle normy SAE J3016 (SAE International, 2018). Klasifikace SAE stanovuje 6 úrovní automatizace (dále jen „L0“ až „L5“). Jednotlivé úrovně se liší podle způsobu ř́izení vozidla, sledování dopravní situace, způsobu reakce na dopravní situaci a prostředí, ve kterých může být vozidlo provozováno. Nejnižší vývojová úroveň L0 značí žádnou (nulovou) automatizaci a veškeré dynamické jízdní úlohy jsou zajišt’ovány řidiči, naopak nejvyšší L5 odpovídá plné automatizaci. Od L3 a L4 již hovoříme o autonomních vozidlech, přičemž dopravní situace je sledována vozidlem.

V př́padě L3 (podmíněná automatizace) musí vozidlo umět reagovat na dynamické dopravní situace zcela autonomně, nicméně $v$ př́padech, kdy tohoto vozidlo není schopno, musí ŕízení převzít řidič. Tento úkon je vyžadován vpř́ípadě náhlé změny podmínek, kdy systémy vozidla nejsou schopny reagovat na dynamickou dopravní situaci (např. ani zastavit u krajnice) a řidič musí provést kriticky manévr v krátkém čase samostatně. Řidič tedy již nemusí neustále sledovat okolní prostředí, nicméně musí řešit případné dynamické dopravní situace (SAE International, 2018).

V př́ípadě L4 (vysoká automatizace) musí vozidlo umět vyřešit dynamické dopravní situace zcela autonomně i bez případného zásahu řidiče. Jinými slovy zpětné převzetí řízeni v tomto typu vozidla nebo režimu jízdy není možné a vozidlo provádí všechny jízdní úkony zcela autonomně. $V$ této úrovni automatizace se již řidič nemusí v předem definovaných situacích a prostředích věnovat řízení ani sledovat okolní prostř̌edí. Pokud však nejsou splněny všechny podmínky, je na rozdíl od nejvyšší úrovně L5, řidič stále potřebný pro převzetí ř́zení (SAE International, 2018).

V praxi může docházet $\mathrm{k}$ tomu, že vozidlové systémy spadající do různých úrovní automatizace budou fungovat pouze $v$ rámci určitých režimů jízdy. Např́ílad vozidla L4 budou provozována pouze na vybraných úsecích dálnic a v případě jízdy mimo dálnici budou vozidlové systémy pouze v L2.

V nákladní dopravě je významný především systém tzv. konvoje (platooning). Systém umožňuje vedení vozidla v konvoji vozidel s minimálními rozestupy mezi vozidly. Rozestup se pohybuje okolo $10 \mathrm{~m}$, v závislosti na rychlosti vozidla a technických parametrech brzdového systému. Řidič vozidla jedoucího v konvoji musí být stále připraven převzít řízeni vozidla v případě, že systém není schopen provést reakci na dynamickou dopravní situaci. Nicméně manévry, které vyžaduji rychlou změnu jízdy, jsou prováděny systémem vozidla např. kritické brzdění (např. Bartels et al., 2015; Kockelman, et al., 2016).

$\mathrm{V}$ současné době se ještě řidiči musí významnou část pracovní doby věnovat právě řízení. Evropské nařízení ES č. 561/2006 v této oblasti stanovuje maximální nebo minimální limity pro doby řízení, bezpečnostní přestávky a doby odpočinku. Mohou řídit maximálně čtyři a půl hodiny, poté musí čerpat bezpečnostní přestávku v délce minimálně 45 minut. Mezi dvěma denními odpočinky může ř́́dit maximálně 9 hodin, přičemž dvakrát týdně může tuto dobu prodloužit až na 10 hodin. Týdenní doba řízení nesmí přesáhnout 56 hodin, ovšem za období dvou po sobě následujících týdnů nesmí celková doba řízení přesáhnout 90 hodin (Evropská unie, 2006).

Tento článek je zaměřen na oblast autonomních nákladních vozidel L3 a L4, u kterých se v budoucnu postupně značně promění pracovní činnosti řidičů, respektive zejména u L4 „mobilních pracovníků“ v kabinách těchto vozidel. Je vhodné se už nyní zamýšlet nad využitím pracovního času těchto osob 
v kabině nákladních vozidel, vytvořit seznamy nezbytných i možných činností a navrhnout možnost klasifikace vykonávaných činnosti do podoby katalogu.

\section{LITERÁRNÍ REŠERŠE}

Pokud se podíváme konkrétněji na činnosti u řidičů, v odborné literatuře existují počáteční př́ístupy pro kategorizaci a hodnocení ne-řidičských aktivit s ohledem na automatizované řízení. Litman (2020) ukazuje, že automatizace může přinést snížení stresu řidiče a zároveň možnost pracovat na cestách, ale konkrétní analýzu možných činností nepřináší. Naproti tomu Petermann-Stock et al. (2013) již uvádí, že ovladatelnost na straně systému a motivační hodnota na straně řidiče se používají jako kritéria pro klasifikaci ne-řidičských aktivit a jsou klasifikována podle využití řidiče. Kromě toho lze klasifikační radu pro ne-řidičské aktivity ve vozidle nalézt ve studiích o rozptylovacím účinku ne-řidičských aktivit (např. Schömig et al., 2015).

Katalogy činností mají široké uplatnění v různých oborech. Slouží k vymezení pracovních činností v oblasti veřejné správy (např. katalog prací ve veřejných službách a správě, katalog činností v bezpečnostních sborech, katalog činností ve školství ...), kde jsou stanoveny správní činnosti a jejich zařazení do jednotlivých platových tříd. Dále jsou klasifikovány ekonomické činnosti pro účely statistické evidence. Klasifikace ekonomických činností (CZ-NACE) je podle Českého statistického úřadu (2021) povinně používána v celé Evropské unii a je rámcem pro získávání a zpracování statistických dat o ekonomických činnostech (např. výroba, zaměstnanost). Konkrétním katalogem činností, který bude využit v tomto výzkumu, je Centrální databáze kompetencí. Ta představuje podle Ministerstva práce a sociálních věcí (2021) autonomní systém pro správu kompetencí, který sjednocuje a udržuje pevné vazby soustavy kompetencí v národních soustavách povolání a kvalifikací.

Jednou ze stěžejních otázek je, jak se jednotlivé ne-řidičské činnosti budou vyvíjet v čase. Např. v oblasti účetních operací existuje předpoklad, že činnosti budou prováděny již plně elektronicky (Güney, 2014) nebo např. vyhledávání podkladů, či sestavování textů bude v budoucnu vykonáváno na základě hlasových pokynů. V současné době je výhled na pracovní trh poměrně nejistý z důvodu pandemie COVID-19. World Economic Forum (2020) ve svém přehledu přesto očekává se, že tempo přijímání technologií zůstane nezmenšené a v některých oblastech se může zrychlit. Mezi nejvýznamnější skupiny dovedností, které zaměstnavatelé považují za důležité, patří skupiny jako kritické myšlení a analýza, řešení problémů a samostatné vedení, aktivní učení, odolnost, tolerance stresu a flexibilita. Velká většina - $84 \%$ zaměstnavatelů je připravena rychle digitalizovat pracovní procesy, včetně významného rozšiřrení práce na dálku, s potenciálem přesunout 44 \% své pracovní síly k práci na dálku (World Economic Forum, 2020).

Další otázkou je, jaký budou mít vývojové trendy v oblasti automatizace dopad na řidiče nákladních vozidel v budoucnu. Průzkumy již identifikovaly různé činnosti, které by mohli řidiči osobních vozidel provádět v době, kdy je dopravní situace sledována vozidlem automaticky: povídat si s ostatními cestujícími, dívat se na video nebo hrát hry, spát nebo dřímat, jíst nebo pít, psát e-maily nebo vyhledávat na internetu, číst si, pracovat se sociálními médii, vyřizovat telefonáty nebo psát SMS zprávy, přemýšlet nebo plánovat, pracovat nebo studovat, sledovat trasu (ve skutečnosti nebo v mapě), (Wadud, 2019; Hecht, et al., 2020).

Zpětné převzetí kontroly řidičem (fallback performance) může být dle Dixit et al. (2016) obecně rozděleno na automatické odpojení a manuální odpojení. Automatické odpojení nastává v okamžiku, kdy systém vyhodnotí, že není schopen zajistit bezpečnost při autonomním řízení, nebo že nastala chyba při autonomním řízení. Zpravidla se jedná o chyby v detekční technologii, komunikaci, činnosti senzorů, map, př́ijmu dat nebo o hardwarovou chybu. Manuální odpojení nastává z vlastní vůle řidiče, který nemá důvěru v bezpečnost autonomního řízení v nastalé situaci. Jedná se zpravidla o špatné povětrnostní podmínky, stavební práce na silnici, špatnou infrastrukturu. Důvodem může být i nespokojenost s autonomním řízením, například změny jízdních pruhů v hustém provozu (Favarò et al., 2017).

Technologie autonomních vozidel L3 a L4 jsou př́slibem odlehčení od nároků dopravního provozu a př́ležitostí pro vykonávání jiné činnosti. Zároveň však představují zvýšené nároky v situacích, kdy se objeví komplikace ve vnějším prostředí nebo selhání autonomních mechanismů. Z hlediska řidiče automatizovaného vozidla je tedy důležité, jaká je reálná možnost zasáhnout v okamžiku, kdy systém hlásí ukončení autonomního módu a žádá, aby řidič převzal zpět kontrolu nad vozidlem. V kritické situaci je 
nutný rychlý a správný zásah, který nemusí proběhnout v př́ípadě, kdy je vykonávána nějaká jiná činnost. Výzkumy se zaměřují na měření reakčních časů a na zmapování okolností, které je mohou ovlivňovat (např. Dixit, et al., 2016; Dogan et al., 2017; Eriksson, et al., 2017; Merat et al., 2014) a na obecné mapování interakce mezi člověkem a systémy ve vozidle při rizikových situacích vyžadujících převzetí kontroly nad vozidlem nebo interakce se systémy varování před kolizí. Weyer et al. (2015) empiricky ověřovali hypotézu o negativním prožívání ztráty kontroly ve vysoce automatizovaných systémech. Dle jejich závěrů se řidiči v reálném provozu většinou cítí s asistenčními systémy spokojeni a jejich spokojenost se naopak zvyšuje, pokud jsou implementovány systémy další.

Z uvedeného je patrné, že se jedná o „převzetí řízení, nikoli o „plné převzetí kontroly“. Výzkumy se v této souvislosti věnují řadě interferujících faktorů, jako je očekávanost převzetí, věnování pozornosti činnostem, které s řízením plně nesouvisejí a v neposlední řadě složitost dopravní situace. Je-li situace na bočních a zadním výhledu komplikovaná, plné převzetí kontroly přesahuje prostý reakční čas na úrovni jednoduchého brždění. Merat et al. (2014) na základě své simulátorové studie formulovali „pohodlný přechodový čas" (comfortable transition time), který definovali jako čas potřebný k dosažení adekvátní stabilní kontroly nad vozidlem při zpětném převzetí kontroly při manuálním ř́izení, který je obdobný u většiny řidičù. Tento čas stanovili okolo 40 vteřin. Gold et al. (2013) simulátorovým experimentem potvrzují, že s kratším časem pro zpětné převzetí kontroly řidičem jsou reakce a rozhodnutí rychlejší, ale obecně horší kvality.

V obecné rovině může dle Kockelmana, et al. (2016) automatizace L3 a L4 kompenzovat chyby lidského faktoru způsobené omezeným zrakem, únavou, nadměrnou nebo nedostatečnou reakcí, atp. Schopnosti řidiče na rozhraní řidič-vozidlo jsou jádrem obav o bezpečnost (Favarò et al. 2017). Sdílená odpovědnost řidiče a autonomní technologie může vyvolávat tendence zbavování se zodpovědnosti u člověka a zároveň vyžaduje obežretnější legislativní úvahy. K tomu Kockelman, et al. (2016) zdůrazňují koncept „kompenzace rizik“, jež představuje problém, který je třeba brát v úvahu při vylepšování systémů. Vyšší bezpečnost může vést $\mathrm{k}$ podstupování vyššího rizika. Vědomí vyšší bezpečnosti může vést chodce a cyklisty k vyhledávání rizikovější, ale rychlejší cesty skrz křižovatky nebo podél silnic $s$ hustým provozem. U řidičů může vědomí vyšší bezpečnosti vést ke snížení pozornosti, což v praxi dokládají Dixit et al. (2016). Kompenzace rizik je tak jednou z klíčových proměnných, kterou je potřeba zahrnout.

\section{METODY}

Metodický postup tvorby konceptu katalogu ne-řidičských činností spočívá v genezi jednotlivých činností v 3.1, následné analýze identifikovaných činností v 3.2 a konečné klasifikaci činností v 3.3. Segmentovaný proces vývoje je znázorněn na oObr. 1 .

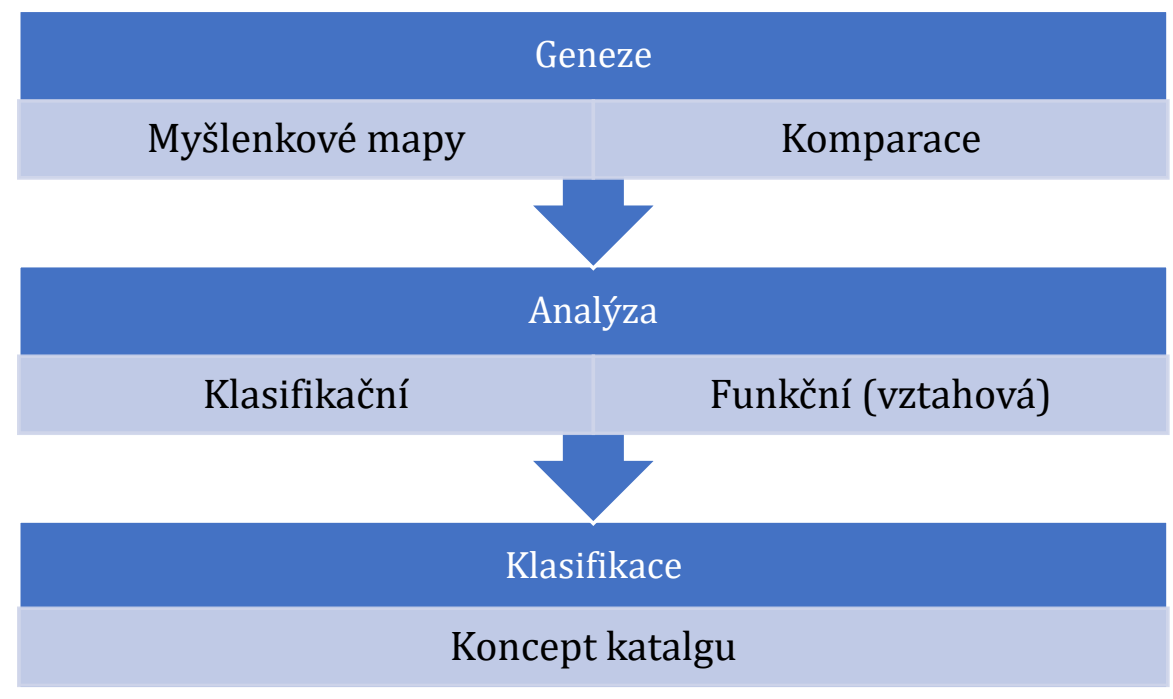

Obr. 1 Proces vývoje; zdroj: vlastní 


\subsection{Geneze činností}

Myšlenkové mapy (mind maps) představují induktivní metodu tvořivého myšlení v souvislostech. Tony Buzan (2012), autor myšlenkových map, je definuje takto: Myšlenková mapa je vizuální nástroj pro holistické myšlení, který podporuje všechny funkce mozku - především pamět', kreativitu, učení a veškeré přemýšlení. Podle Buzana (2012) je myšlenková mapa technika zlepšující kreativitu i produktivitu, která dokáže podpořit schopnost učit se i výkonnost jedince i organizací. Je to systém sloužící k zachycování nápadů a poznatků na papír.

Pro zpracování myšlenkové mapy ne-řidičských činností byl zvolen software Coggle (2013). Jedná se o volně dostupný nástroj, který umožňuje uživatelsky přátelským způsobem vytvářet myšlenkové mapy v pěkném designu, který zvýrazňuje návaznosti a podporuje kreativitu. Mapy vytvořené v tomto software jsou velmi podobné mapám publikovaným Tony Buzanem. Mapy lze v software Coggle také sdílet a tvořit on-line v širších vzdálených týmech.

Komparace umožňuje stanovit shody a rozdíly jevů či objektů. Podle Širokého et al. (2011) se při srovnávání zjišt'ují shodné či rozdílné stránky různých předmětů, jevů, úkazů či ukazatelů. Srovnávací kritérium může být vymezeno věcně, prostorově nebo časově.

V podstatě existuje dvojí způsob srovnávání:

- Srovnávání pojetí problémů, názorů, premis jako vytváření, ověřování či zdůvodňování vlastního stanoviska (postupu, úvah),

- Srovnávání jako nástroj měření, zjišțování, objektivizace a hodnocení dosažených výsledků (např. ukazatelů).

Na základě komparace lze vyslovovat vědecké závěry, nicméně není to vědecká metoda nevyvratitelná a samotnou komparaci nelze použít jako př́mý vědecký důkaz (Široký et al., 2011).

Metoda komparace byla použita pro porovnání současných definic pracovních náplní vybraných pracovních pozic v kontextu toho, zda by mohly být potenciálně vykonávány budoucími řidiči nákladních vozidel úrovně automatizace L3 nebo L4. Zdrojem informací byla Centrální databáze kompetencí (Ministerstvo práce a sociálních věcí, 2021), kde byly nalezeny ne-řidičské činnosti, které by mohly být využity a klasifikovány v katalogu.

\subsection{Analýza činností}

Analýza je vědecká metoda založená na dekompozici celku na elementární části, je to metoda zkoumání složitějších skutečností rozkladem na jednodušší, základní celky (Danel, 2017).

Byla provedena analýza možných ne-řidičských činností, které jsou svým charakterem vhodné k tomu, aby je řidiči mohli vykonávat v době, kdy je v úrovni L3 a L4 dopravní situace sledována vozidlem.

Cílem analýzy bylo především analyzovat obecné charakteristiky jednotlivých ne-řidičských činností, poznat jejich podstatu, zákonitosti a možný vliv na případné převzetí ř́zení.

Byly použity dvě analytické metody:

- klasifikační analýza - třídění ne-řidičských činností do skupin,

- funkční (vztahová) analýza - hledání závislostí mezi jednotlivými ne-řidičskými a řidičskými činnostmi, tento typ analýzy je zaměřen na strukturu.

\subsection{Klasifikace činností}

Statistická klasifikace představuje hierarchicky uspořádané třídění určitých ekonomických, sociálních nebo demografických jevů či procesů. Klasifikační třídění sleduje návaznost jevů a procesů od obecnějšího $\mathrm{k}$ detailnějšímu. Jevy a procesy jsou v klasifikacích uspořádány a rozčleněny zpravidla do tříd a podtř́íd, skupin a podskupin, oddílů a pododdílů, kdy vyšší stupeň struktury se rozkládá na detailnější nižší stupně a existuje hierarchické logické uspořádání podřizení a nadřazení jednotlivých stupňů klasifikace (Český statistický úřad, 2021). 
Metoda byla využita pro zpracování formální struktury konceptu katalogu ne-řidičských činností.

Klasifikace ne-řidičských činností představuje jejich tř́́dění a kódování z hlediska typu a obsahu. Klasifikace je dána číselnými kódy kategorizujícími činnosti minimálně ve čtyřech úrovních (úroveň automatizace, dopravní prostředek, činnost, specifikace činnosti).

\section{VÝSLEDKY A DISKUSE}

Struktura této kapitoly odpovídá předchozí kapitole 3 - Metody. Obsahuje popis použití dvou metod pro genezi činností v 4.1, na které jsou následně aplikovány dvě metody analýzy v 4.2. Výsledkem je návrh první verze katalogu ne-řidičských činností v 4.3. Katalog je určen pro úroveň automatizace L3 a L4. Další členění je prováděno dle druhu dopravního prostředku, dle jednotlivých činností a její specifikací.

\subsection{Geneze činností}

Jako první krok byla provedena geneze ne-řidičských činností. $\mathrm{K}$ tomu byla v 4.1 .1 použita myšlenková mapa, která je heslovitá a přehledně zobrazuje vazby a souvislosti pro další analýzy. Ne-řidičské činnosti byly rozčleněny podle následujících kritérií:

- rozšiřující pracovní činnosti a přímo zvyšující produktivitu práce řidiče,

- zvyšující kvalifikaci řidiče,

- sloužící k odpočinku a relaxaci řidiče.

Dále byla v 4.1.2 provedena komparace jednotlivých činností podle vybraných srovnávacích kritérií. Pro tento účel byly jako příklad vybrány činnosti povolání dispečer silniční dopravy, u kterých bylo posuzováno, zda vyhovují dvěma definovaným kritériím, zaměřeným na možnost výkonu činnosti v kabině vozidla a možnost zpětného převzetí rízení.

\subsubsection{Myšlenkové mapy}

Podle metodologie uvedené v Buzanovi (2012) bylo postupováno v následujících krocích:

1. ve středu mapy je zachycen hlavní objekt naší pozornosti - v našem případě ne-řidičské aktivity, ilustrativně doplněné siluetou nákladního vozidla,

2. ze středu vyrůstají různé větve. Nejdříve jsou to hlavní témata, která přímo souvisejí s centrálním obrázkem, následně se štěpí na další, vzdálenější motivy - v našem př́ípadě jsme identifikovali šest hlavních témat a jednotlivé větve barevně odlišili pro větší přehlednost,

3. každá větev je popsána klíčovým slovem nebo ilustrací - v našem př́ípadě jsme volili jednoduchá klíčová slova.

Myšlenková mapa je na Obr. 2. 


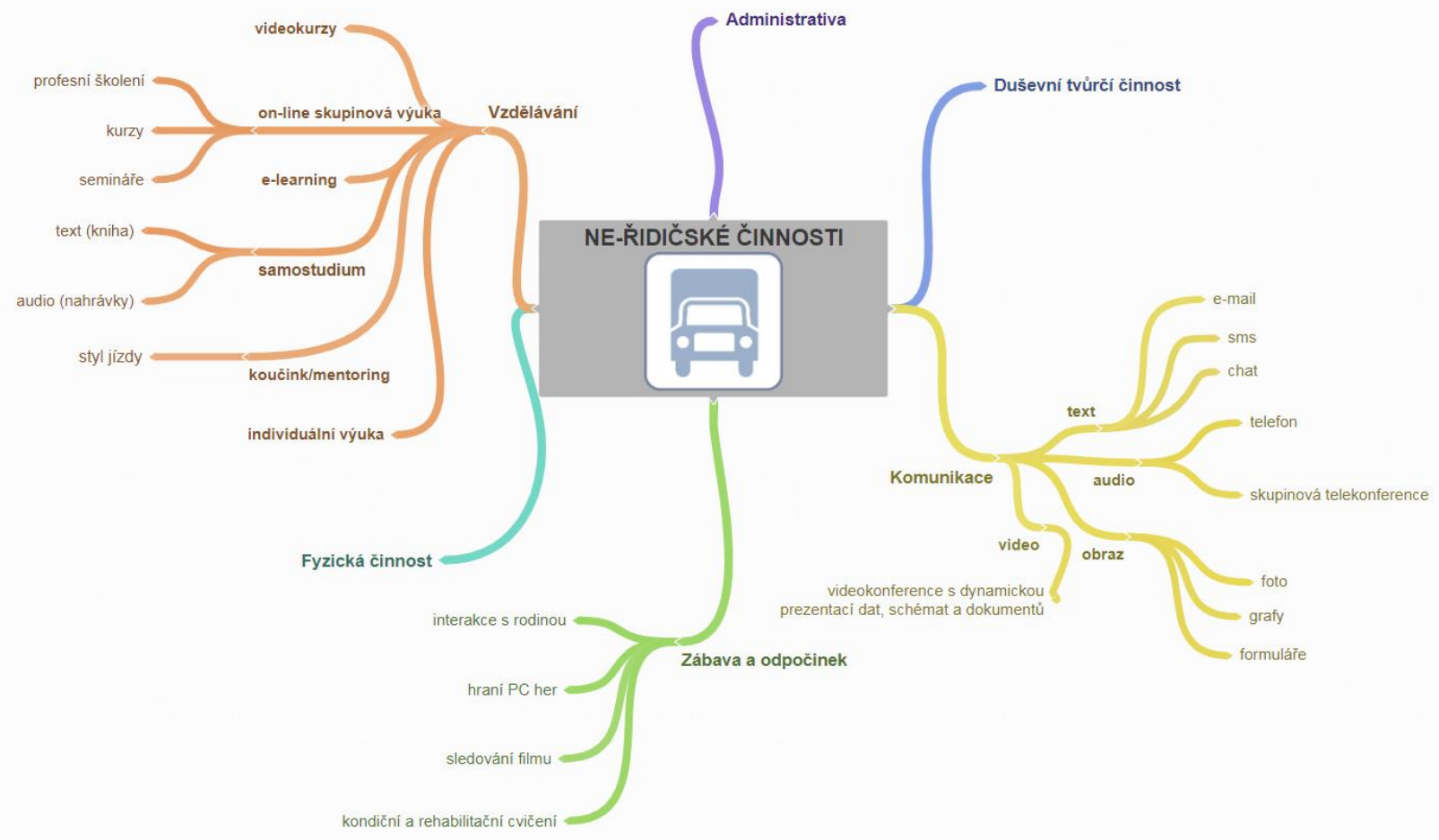

Obr. 2 Myšlenková mapa; zdroj: vlastní s využitím software Coggle

\subsubsection{Komparace činností}

Jako příklad byly pro komparaci vybrány činnosti dispečera silniční dopravy, uvedené v Centrální databázi kompetencí (Ministerstvo práce a sociálních věcí, 2021). Dispečer silniční dopravy se stará o zajištění, řízení přepravy a vyhledávání optimálního řešení přepravy zboží, popřípadě materiálu včetně plánování vhodné trasy a vytíženosti jednotlivých dopravních prostředků, komunikuje a spolupracuje s dodavateli, zákazníky a ostatními odděleními organizace a řeší vzniklé problémy. Pracovní náplň současných dispečerů tak přímo souvisí s prací řidičů.

Jednotlivé činnosti, které dispečer vykonává, byly posouzeny (komparovány), zda odpovídají dvěma kritériím:

- $\quad$ kritérium 1 - Může být činnost vykonávána v kabině vozidla, když je v úrovni L3 a L4 dopravní situace sledována vozidlem?

- kritérium 2 - Bude řidič při dané činnosti hypoteticky schopen převzít řízení, pokud k tomu bude vyzván systémem autonomního vozidla?

Do další analýzy a klasifikace pak postupují činnosti, které splňují obě omezující podmínky (kritéria). Zpracování komparace pracovních činností dispečera je v Tab. 1.

Tab. 1 Komparace pracovních činností pozice dispečer; zdroj: Centrální databáze kompetencí, zpracování vlastní 


\begin{tabular}{lcc}
\hline Sjednávání zakázek pro vytěžování vozidel & ano & ne \\
Organizace dopravy & ano & ano \\
Plánování tras s ohledem na hospodárnost přeprav & ano & ano \\
Organizace a řízení práce řidičů & ano & ne \\
Řízení přeprav v reálném čase & ne & ano \\
Kontrola průběhu přeprav & ne & ano \\
Vedení, kontrola a vyhodnocování příslušné dokumentace & ano & ano \\
Posuzování a vyhodnocování kontrol a průzkumů & ano & ano \\
Koordinace činností s ostatními úseky organizace & ano & ano \\
Kalkulace cen přepravy & ano & ano \\
\hline
\end{tabular}

\subsection{Analýza činností}

Pro analýzu činností byla stanovena klasifikační kritéria, která slouží ke třídění ne-řidičských činností do skupin v 4.2.1. Podle těchto kritérií byly v návaznosti na myšlenkovou mapu činnosti rozděleny do šesti charakteristických skupin a několika podskupin. Následně byly v 4.2.2 analyzovány stanovené skupiny/podskupiny a posouzeny vztahy mezi nimi. Byly zohledněny vstupní předpoklady neboli kvalifikace $\mathrm{k}$ výkonu dané činnosti, psychická náročnost výkonu činnosti a dále vhodnost provádění pracovní činnosti při úrovni automatizace L3, respektive potřeba spolupráce.

\subsubsection{Klasifikační analýza}

Klasifikační analýza navazuje na činnosti generované v předchozím kroku pomocí myšlenkové mapy (viz Obr. 2).

Kritéria zařazení činnosti do klasifikace:

- činnost lze provádět v kabině nákladního vozidla nyní, nebo je tento předpoklad v budoucnu,

- řidič bude při činnosti hypoteticky schopen převzít ř́izení, pokud k tomu bude vyzván v závislosti na úrovni automatizace vozidla,

- činnost přispěje k růstu produktivity práce, kvalifikace nebo odpočinku řidiče,

- indiferentní, jaké nástroje, elektronická zařízení nebo software bude nutno zajistit,

- vyjmuté vysoce specializované činnosti, u kterých není předpoklad zajištění řidičem (např. právní služby, ...).

Základní členění ne-řidičských činností je znázorněné na Obr. 3. Jsou zde čtyři základní skupiny (duševní tvůrčí činnost, komunikace, administrativa, fyzická činnost) přímo zvyšující produktivitu práce řidiče v porovnání se současným konceptem pojetí jeho práce. Pátá skupina „Vzdělávání“ má přímou vazbu na zvýšení produktivity práce v budoucnu. Poslední samostatná skupina „zábava a odpočinek“ taktéž popisuje činnosti řidiče, ze kterých v konečném důsledku může mít užitek zaměstnavatel. Pokud si řidič během jízdy autonomního vozidla dokáže částečně odpočinout, může být schopen řídit vozidlo delší dobu či provést více přeprav. Vzdělávání i zábava a odpočinek jsou však činnosti odlišného typu, bez primární pracovní činnosti, a proto mají přiřazené i nejvyšší číslice „, 8 “ respektive „"9“. Neobsazené číslice „5“ až „7“ poskytují možnost rozšíření budoucího katalogu o další skupiny činností přímo zvyšující produktivitu práce řidičů. 


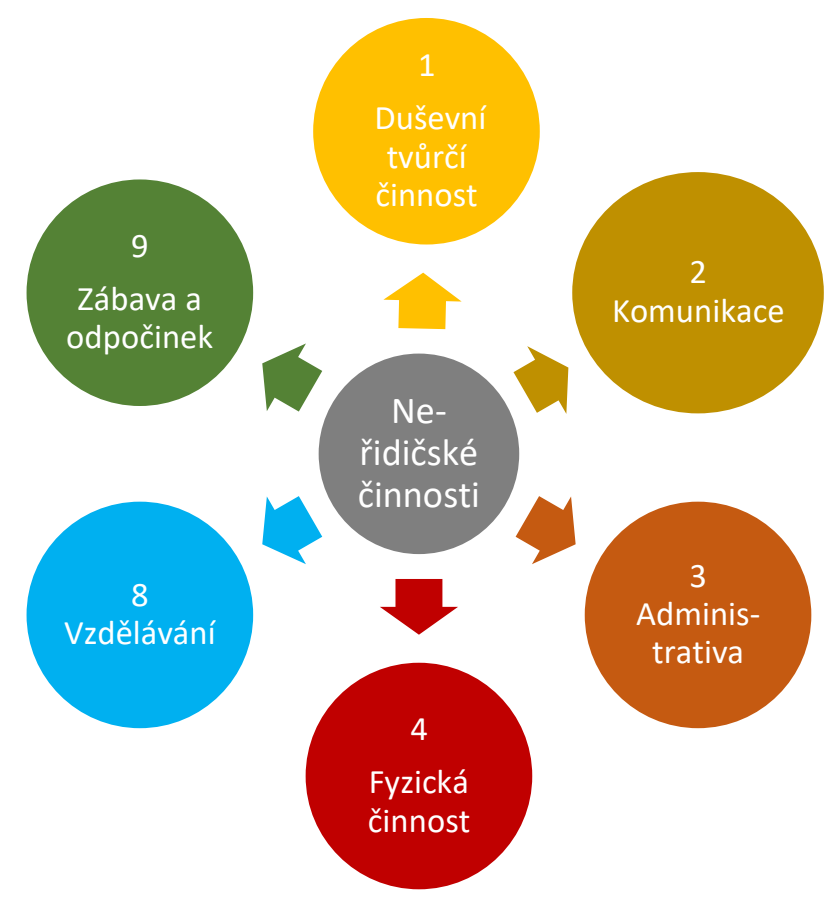

Obr. 3 Klasifikační analýza skupin ne-řidičských činností; zdroj: vlastní

$\mathrm{Na}$

Obr. 4 je jako př́íklad znázorněna klasifikační analýza podskupin „vdělávání“ a „komunikace“.
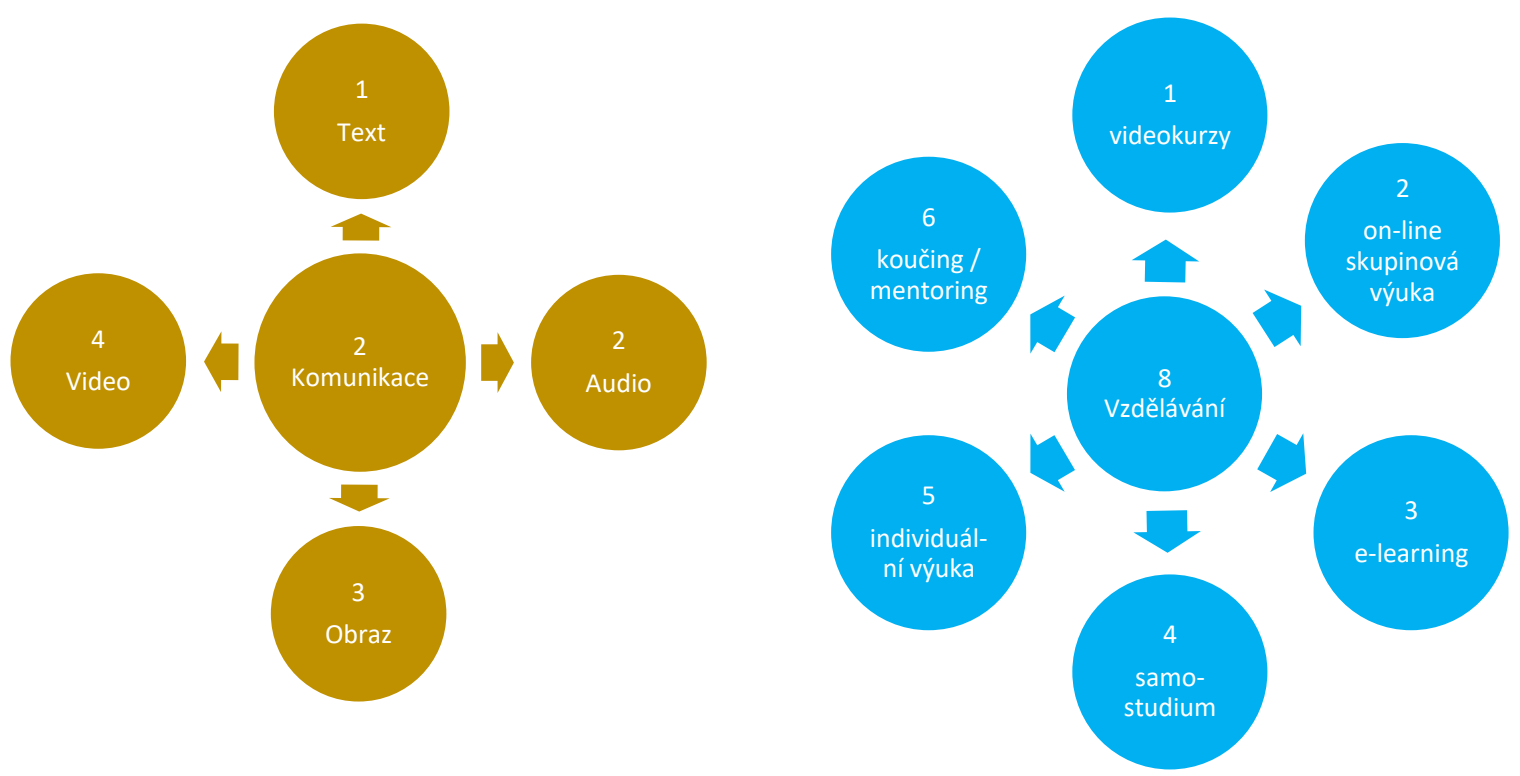

Obr. 4 Klasifikační analýza podskupiny „vzdělávání (vlevo) a podskupiny komunikace (vpravo); zdroj: vlastní

Pokročilejší přístup k této analýze by mohl spočívat v barevném zvýraznění podobných činností, případně by se jednotlivé množiny mohly v grafice částečně překrývat, pokud mají dané činnosti do jisté míry shodné parametry. Tento prŕstup by mohl lépe pomoci rozhodnout, zda je vhodné pro danou činnost stanovit v budoucím katalogu samostatnou kategorii (číslo), anebo ji sloučit s nebližší podobnou kategorií. 


\subsubsection{Funkční (vztahová) analýza}

Ve funkční analýze byly z různých hledisek posuzovány činnosti identifikované v předchozích krocích pomocí myšlenkové mapy (4.1.1) či komparací (4.1.2). 
Jako př́́klad jsou v Tab. 1Tab. 2 uvedeny činnosti ze skupin:

- 1 - komunikace,

- 2 - vzdělávání.

U jednotlivých činností byl posuzován vztah k potřebné kvalifikaci (schopnostem a vstupním předpokladům) osoby vykonávající danou činnost a psychická (mentální) náročnost výkonu činnosti. Každé kritérium má škálu 1 - 5 bodů $(1$ - nejméně, 5 - nejvíce). Všechny uvedené činnosti jsou vhodné pro úroveň automatizace L4. Binárně pak bylo posouzeno, zda je danou činnost vhodné vykonávat i při úrovni automatizace L3.

Tab. 2 Funkční analýza vybraných skupin činností; zdroj: vlastní

\begin{tabular}{|c|c|c|c|c|}
\hline Druh činnosti & Činnost & Kvalifikace & Náročnost & Úroveň L3 \\
\hline text (e-mail, sms, chat) & 1 & 2 & 3 & ano \\
\hline $\begin{array}{l}\text { audio (telefon, skupinová } \\
\text { telekonference) }\end{array}$ & 1 & 1 & 2 & ano \\
\hline obraz (foto, grafy, formuláře) & 1 & 2 & 3 & ano \\
\hline $\begin{array}{l}\text { video (videokonference s dynamickou } \\
\text { prezentací dat, schémat, dokumentů) }\end{array}$ & 1 & 3 & 3 & ne \\
\hline $\begin{array}{l}\text { on-line skupinová výuka (profesní } \\
\text { školení, kurzy, semináře) }\end{array}$ & 2 & 2 & 4 & ne \\
\hline videokurzy & 2 & 2 & 4 & ano \\
\hline e-learning & 2 & 3 & 3 & ano \\
\hline $\begin{array}{l}\text { samostudium (e-kniha, audio } \\
\text { nahrávky) }\end{array}$ & 2 & 3 & 3 & ano \\
\hline koučink/mentoring (styl jízdy) & 2 & 3 & 3 & ne \\
\hline
\end{tabular}

Kritérium „úroveň L3“ je zřejmé a př́mo slouží k determinaci, zda danou činnost zařadit do části katalogu zaměřenou na tuto úroveň automatizace. Kritérium „náročnost“ zohledňuje psychickou zátěž vyplývající z výkonu dané činnosti a slouží k posouzení únavy řidiče. Tím přímo ovlivňuje předpokládanou maximální dobu výkonu této činnosti. Naproti tomu kritérium „kvalifikace“ neboli vstupní předpoklady prŕmo předurčuje, jakou množinu činností potenciálně může vykonávat osoba s určitou úrovní kvalifikace.

Autoři si jsou vědomi poměrně velkého zjednodušení při aplikaci prezentované škály $1-5$. Hodnocení je v této fázi nepochybně subjektivní a vyžaduje přezkoumání a kritiku v rámci širšího řešitelského týmu, což je podrobněji rozvedeno v závěru tohoto článku. Je třeba taktéž zohlednit budoucí trendy, z nichž některé se na pracovním trhu projevují již nyní. V souladu s World Economic Forum (2020) bude čím dál více převládat požadavek na digitální gramotnost, nové a adaptivní myšlení, týmovou spolupráci a flexibilitu.

Byl představen pouze základní koncept funkční analýzy, což je zcela jistě pouze jedna z cest, jak k dané problematice přistoupit. Zřejmější interpretace vzájemných vazeb bychom pravděpodobně dosáhli grafickou vizualizací, která by např́íklad znázorňovala, jaké kombinace aktivit je možné vykonávat současně a které se vzájemně vylučují - nemohou být vykonávány zároveň. Vstupní předpoklady by v této grafice mohly být znázorněny barevně - červený rámeček by např. znamenal požadavek na počítačovou gramotnost, pokud bude zároveň i modrý jsou vyžadované organizační schopnosti apod.

Davies et al. (2011) identifikovali virtuální kolaboraci jako jednu z klíčových schopností pracovníků v budoucnu. Jako př́klad bylo kritérium „spolupráce“ posuzované v Tab. 3. Vstupní parametry byly činnosti povolání „dispečer“, které v rámci předchozího kroku komparace získaly „ano“ v obou hodnotících kritériích (viz Tab. 1). 
Tab. 3 Funkční analýza činností dispečera; zdroj: vlastní

\begin{tabular}{lccc}
\hline Činnosti dispečera & Kvalifikace & Náročnost & Spolupráce \\
\hline Organizace dopravy & 3 & 4 & ano \\
Plánování tras s ohledem na hospodárnost přeprav & 2 & 3 & ne \\
Vedení, kontrola a vyhodnocování př́slušné & 2 & 3 & ne \\
dokumentace & & 2 & ano \\
Posuzování a vyhodnocování kontrol a průzkumů & 2 & 2 & ano \\
Koordinace činností s ostatními úseky organizace & 3 & 2 & ne \\
Kalkulace cen přepravy & 2 & 2 & \\
\hline
\end{tabular}

Jedno z nejdůležitějších kritérií, které musí být zohledněno při objektivním posouzení implementace dané činnosti do pracovní náplně řidičů, je časová prodleva mezi výkonem dané činnosti a zpětným převzetím řízení, pokud k tomu bude řidič vozidlem vyzván. Pro exaktní stanovení tohoto času doporučujeme využít v souladu např. s Doganem, et al. (2017) a Erikssonem, et al. (2017) vozidlový simulátor, jak je podrobněji uvedeno v závěru tohoto článku.

\subsection{Koncept katalogu}

Navržená první verze katalogu ne-řidičských činností řidičů (viz Obr. 5) zahrnuje formální strukturu číselného řetězce založeného na kombinaci celých nezáporných reálných čísel. Systematická struktura katalogu obsahuje číselné kódy kategorizující činnosti minimálně ve čtyřech úrovních (nadřazená úroveň, základní úroveň, první podskupina, druhá podskupina). Katalog je zaměřen na dvě úrovně automatizace L3 a L4, které představují činnosti v nadřazené úrovni (A) klasifikace katalogu. V základní úrovni (a) je specifikace dopravního prostředku. Následují dvě kategorie podskupin určující činnost (b) viz Obr. 3 a její specifikaci (cc), prŕíklady viz Obr. 4.

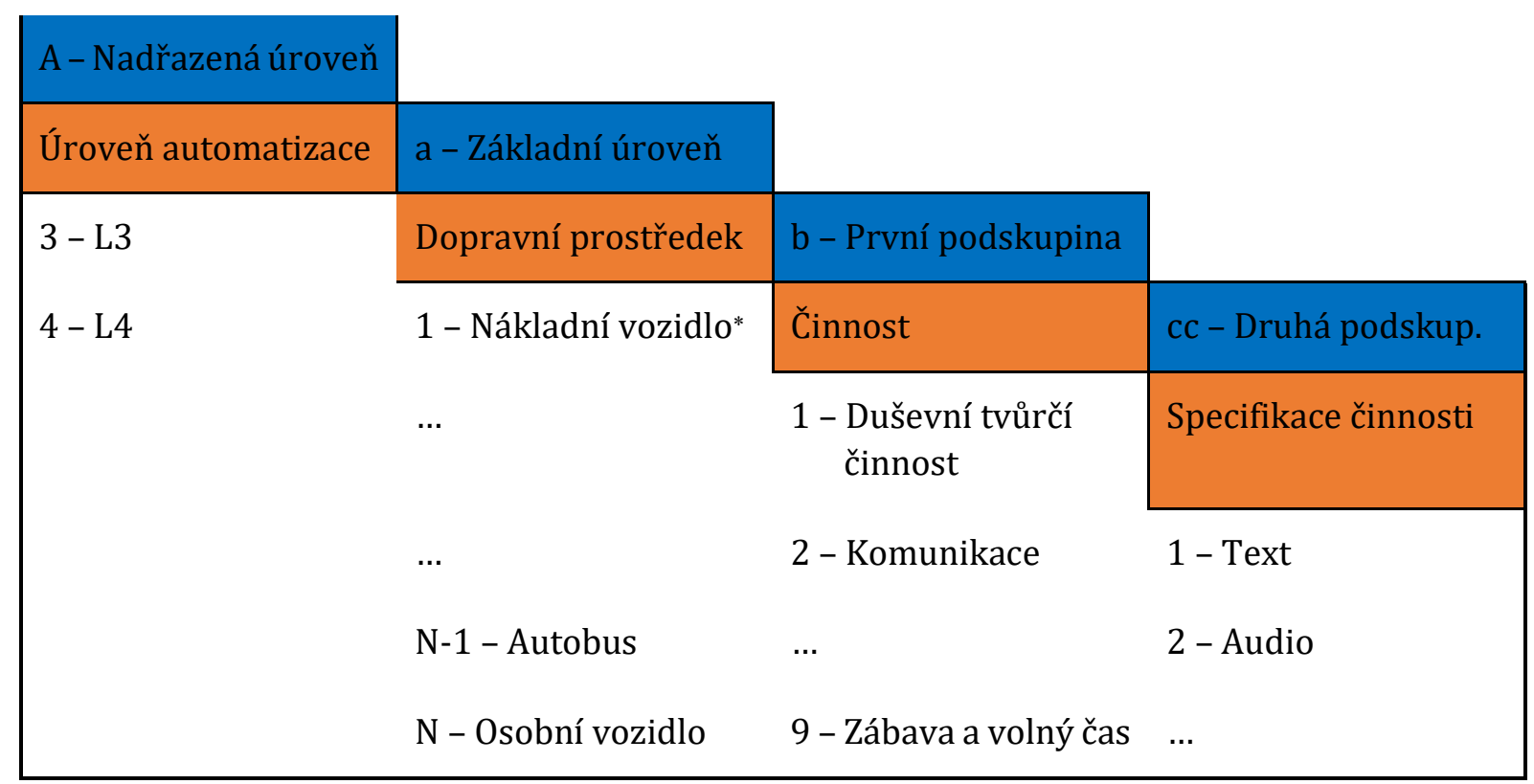

Obr. 5 Koncept katalogu ne-řidičských činností řidičů; zdroj: vlastní

* Samostatné motorové nákladní vozidlo kategorie N2, N3 nebo v soupravě s prípojným vozidlem 03, 04 podle př́lohy č. 2 k vyhlášce č. 341/2014 Sb. 
Struktura každého katalogového čísla má formát „A a b cc“, kde:

- A - jednociferná binární číslice 3 nebo 4,

- $\mathrm{a}, \mathrm{b}$ - jednociferná desítková číslice 1 až n,

- cc - dvojciferná desítková číslice 01 až nn.

Příkladem je katalogové číslo: „3 12 01“. Význam pro jednotlivé úrovně katalogu:

- úroveň automatizace: L3,

- dopravní prostředek: nákladní vozidlo,

- činnost: komunikace,

- specifikace činnosti: text (např. e-mail).

Na Obr. 6 je znázorněna hierarchie jednotlivých úrovní katalogu na příkladu katalogového čísla „31201“.

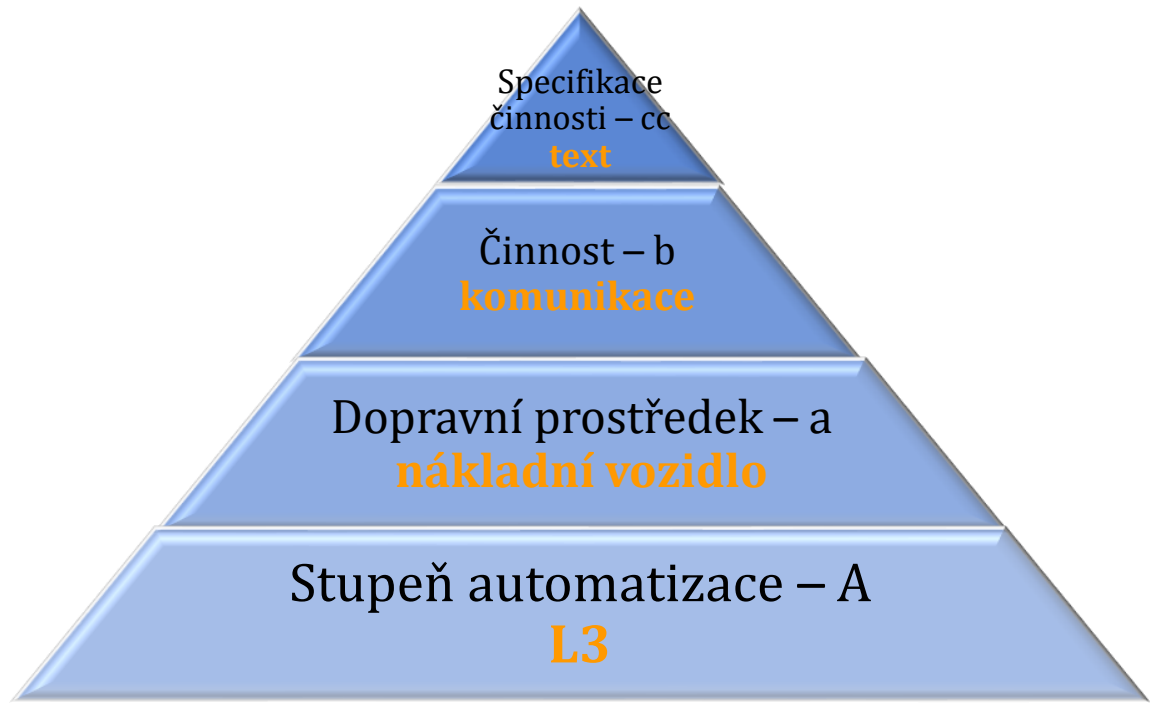

Obr. 6 Hierarchie úrovní katalogu; zdroj: vlastní

Další možnost rozvoje katalogu je rozšíření čtyřstupňové úrovně o pátou úroveň (třetí podskupinu - dd), která by v uvedeném př́kladu determinovala, zda se napřr. jedná o e-mail, SMS, chat apod.

Do katalogu by také bylo vhodné zakomponovat ne-řidičské činnosti, které jsou přímo spojené se zajištěním přepravy zboží (např. nakládka a vykládka zboží, upevnění nákladu), avšak řidiči ani jiní pracovníci je nemohou vykonávat $\mathrm{v}$ době autonomního pohybu vozidla. Řešením by např. mohlo být použití číslice 0 místo úvodní číslice 3 nebo 4 . Katalogové číslo by pak mělo formát „0 a b cc“, jelikož je tato činnost indiferentní na úrovni automatizace vozidla.

Zavádění jednotlivých úrovní automatizace do praxe bude probíhat postupně nejen v závislosti na kategorii dálnice či silnice, ale také s ohledem na specifika typů nákladních přeprav (nebezpečné věci, zboží vysoké hodnoty, živá zvířata) a vnímání rizika společností. V souladu se závěry Kockelmana, et al. (2016); Favaròa et al. (2017) a Dixita et al. (2016) bude u každé činnosti následně nutné určit potenciální riziko negativního dopadu na bezpečnost provozu v důsledku včasného nepřevzetí manuálního řízení, nebo nesprávného převzetí vlivem nepřiměřené distrakce řidiče touto činností. Dále bude u každé činnosti vhodné určit míru komfortu pro řidiče neboli motivace vykonávat danou činnost a také prŕnos pro zaměstnavatele (dopravce).

Rozvoj automatizace a s ním spojené vykonávání ne-řidičských činností také pravděpodobně změní současné sociální předpisy v silniční dopravě (nařízení ES č. 561/2006). Jedná se zejména o přehodnocení délky doby řízení, bezpečnostních přestávek a odpočinku, a to s ohledem na činnosti vykonávané $\mathrm{v}$ době, kdy je řízení vozidla prováděno autonomně. Evropský parlament ve svém Postoji k přijetí nařízení Evropského parlamentu a Rady (EU), kterým se mění nařízení ES č. 561/2006, pokud jde o minimální požadavky na maximální denní a týdenní dobu řízení, minimální přestávky v řízení a týdenní doby odpočinku, a nařízení (EU) č. 165/2014, pokud jde o určování polohy pomocí tachografů (Evropská unie, 2019) uvádí, že v budoucnu by autonomní systémy mohly umožnit různé způsoby využití vozidel, 
k jejichž provozu není zapotřebí řidiče. Výsledkem by mohly být nové možnosti provozu, jako je jízda nákladních automobilů v konvoji. $V$ důsledku toho bude zapotřebí aktualizovat současné právní předpisy, včetně předpisů upravujících dobu řízení a odpočinku. Maximální dovolená doba řízení, respektive dohledu nad autonomním ř́zením, by mohla být prodloužena, ale musí být zohledněn fakt, že řidič během doby, kdy aktivně neřídí vozidlo, provádí jiné práce, které mohou být taktéž náročné na jeho soustředění a způsobují jeho únavu. Tento trend je také uveden př́mo v článku 9a nařízení ES č. 561/2006. Do 31. prosince 2025 Komise vypracuje a předloží Evropskému parlamentu a Radě zprávu hodnotící používání autonomních systémù řízení v členských státech. Tato zpráva se zaměří zejména na potenciální dopad těchto systémů na pravidla týkající se doby ř́zení a odpočinku. Ve vhodných případech je k ní přiložen legislativní návrh na změnu tohoto nařízení (Evropská unie, 2006).

Na druhou stranu ve Spojených státech podala firma Pronto.ai žádost o prodloužení pracovní doby řidičů nákladních vozidel vybavených jejím systémem autonomního řízení až na 13 hodin během 15 hodinové pracovní směny. Tato žádost se setkala s obrovskou opozicí a úřad FMCSA (2020), (Federal Motor Carrier Safety Administration), ji zamítl. Je tedy zřejmé, že bude nutné dále ověřit vliv rozvoje autonomních technologií na fyzické a psychické zatížení řidičůu, než dojde k politickému konsensu na změně povolené doby řízení.

\section{ZÁVĚR}

V článku byl představen koncept katalogu ne-řidičských činností řidičů nákladních vozidel v návaznosti na budoucí rozvoj technologií autonomního řízení vozidel. Návrh katalogu je zaměřen na dvě základní úrovně automatizace vozidel L3 a L4 dle SAE. Systematická struktura katalogu je založena na číselných kódech kategorizujících činnosti minimálně ve čtyřech úrovních. V článku jsou systematizovány oblasti činností: duševní tvůrčí činnost; komunikace; administrativa; fyzická činnost; vzdělávání; zábava a odpočinek. Součástí je příklad vyplnění katalogu pro snazší pochopení jako použití a diskuse nad možnými implikacemi trendu rozvoje automatizace v nákladní dopravě i samotného katalogu.

Automatizace vozidel bude mít dopad na různé oblasti lidské činnosti i trh práce. Pravděpodobně dojde ke snížení nároku na kvantitu lidských zdrojů, ale naopak se zvýší nároky na kvalitu těchto zdrojů z důvodu mnohem komplexnějších a kvalifikovanějších činností budoucích řidičů (manažerů kabiny vozidla). Dojde ke snížení chybovosti lidského faktoru. Zároveň bude možné hodnotit vliv každé jednotlivé ne-řidičské činnosti na bezpečnost řízení, což bude umožněno automatickým záznamem průběhu jízdy. Při řízení autonomního vozidla bude řidič především v roli kontrolora autonomního systému. Tato kontrolní úloha vyžaduje schopnosti odlišné od schopností nutných pro běžné řízení manuálních vozidel. Zvýší se produktivita práce řidičů, a tím i silniční nákladní dopravy. Zároveň musí být dosaženo podobné či vyšší zvýšení efektivity i u ostatních přepravních módů, pokud mají být naplněny cíle EU v podobě převodu přepravních výkonů na železnici a vnitrozemské vodní cesty.

Katalog ne-řidičských činností řidičů musí splňovat požadavky, jak jsou známy z oblasti katalogů prací, projektování, př́padně ze statistické nomenklatury EU, tj. rychlý přístup k informacím, transparentnost struktury, konzistence, úplnost v rámci definovaného úhlu pohledu a schopnost rozšíření katalogu.

Katalog bude sloužit zejména manažerům dopravních firem pro tvorbu skladby práce řidičů a dalších zaměstnanců a lepší plánování jejich činnosti i organizace celé firmy. Aplikace katalogu vedoucími manažery umožní v budoucnu zvýšit efektivitu pracovního času řidičů a potažmo celého přepravního systému silniční nákladní dopravy s pozitivními dopady na koncového uživatele. Další uživatelé budou ústřední orgány státní správy a odborné organizace v dopravě pro znalostní plánování a určování koncepce dopravního systému. Katalog by také mohl vést k lepšímu porozumění požadavkům na kvalifikaci a schopnosti budoucích řidičů, na které budou moci vhodně reagovat instituce zaměřující se na oblast vzdělávání v dopravě (SŠ, VŠ, autoškoly, ...).

Pro praktické využití katalogu by bylo vhodné jej digitalizovat pro intuitivní a komfortní práci uživatelů. Katalog by měl být naprogramován robustně v blokové podobě, aby byla možnost jeho postupného rozvoje a doplnění např. na základě ověření jednotlivých činností na simulátoru nákladního vozidla. 
V neposlední řadě je třeba zdůraznit, že tento článek je zaměřen pouze na činnosti řidičů v autonomním nákladním vozidle či soupravě. Tato základní úroveň však umožňuje rozšíření katalogu ne-řidičských činností i na další dopravní prostředky (autobusy, osobní vozidla, traktory, motocykly, ...). Analogicky je předpoklad budoucího rozšiŕení katalogu v nadřazené úrovni o úroveň automatizace L5, pokud to bude pro tuto úroveň ještě dávat smysl.

V další fázi doporučujeme optimalizovat navržený koncept katalogu ne-řidičských činností řidičů a identifikovat možnosti jeho rozšíření. Optimalizaci a rozvoj katalogu navrhujeme dvěma cestami workshopem s experty (1) a dotazníkem či strukturovaným rozhovorem $\mathbf{s}$ řidiči nákladních automobilů (2). Ne-řidičské činnosti se také liší v délce reakční doby při zpětném převzetí řízení. Verifikaci a určení rizika výkonu jednotlivých činností navrhujeme s využitím simulátoru nákladního vozidla (3).

1. Workshop s odborníky na oblast interakce člověka a stroje (Human-Machine Interaction, HMI), automatizace, bezpečnost silničního provozu, vedoucí pracovníky v dopravě apod. Navržený koncept katalogu by byl během workshopu podroben kritické diskuzi a hodnocením.

2. Dotazníkové šetření či strukturovaný rozhovor s řidiči nákladních vozidel potvrdí nebo vyvrátí navržené ne-řidičské činnosti z pohledu těch, kterých se budou nejvíce týkat.

3. Simulátorem by byla ověřena míra distrakce jednotlivými činnostmi. Ve virtuálním dopravním prostředí lze simulovat širokou škálu rizikových scénářủ, různé povrchy vozovky, volitelnou adhezi, jízdu ve dne, v noci, i různé podmínky počasí a tímto zkoumat riziko výkonu činností a zpětného převzetí ŕízení při interakci řidiče s vozidlem různé úrovně automatizace, dopravním prostředím a ostatními účastníky provozu. Předmět výzkumu by konkrétně mohl spočívat v určení vlivu využití různých komunikačních nástrojů při vyřizování elektronické pošty (notebook, mobil, tablet, tablet s externí klávesnicí, klávesnice fyzicky propojená se zařízením vs. bezdrátová klávesnice atd. v členění dle základních výrobců, operačních systémů apod.).

Dílčí poznatky z těchto následných fází by byly použity pro tvorbu dalších vývojových verzí katalogu neřidičských činností řidičů nákladních vozidel, aby tento koncept katalogu mohl být použit jako standard i v mezinárodním prostředí.

\section{Poděkování}

Tento článek byl vytvořen za finanční podpory Ministerstva dopravy v rámci programu dlouhodobého koncepčního rozvoje výzkumných organizací na výzkumné infrastruktuře pořízené z Operačního programu Výzkum a vývoj pro inovace (CZ.1.05/2.1.00/03.0064). Autoři dále děkuji Martinu Bambuškovi, Ondřeji Koutníkovi a Marku Vanžurovi za poskytnuté konzultace.

\section{Literatura}

Bartels, A., Eberle, U. a Knapp, A. 2015. System Classification and Glossary. Deliverable D2.1 AdaptIVe [Online]. Dostupné z: https://www.adaptive-ip.eu/index.php/AdaptIVe-SP2-v12-DL-D2.1System $\% 20$ Classification-file=files-adaptive-content-downloads-Deliverables\%20\&\%20papersAdaptIVe-SP2-v12-DL-D2.1-System\%20Classification.pdf [cit: 10. 02. 2021].

Buzan, T. a Buzan, B. 2012. Myšlenkové mapy. Brno: BizBooks.

COGGLE [software] ㄷ. 2013. Dostupné z: https://coggle.it/ [cit. 25. 01. 2021].

Český statistický úřad (C). 2021. Klasifikace ekonomických činností [Online]. Dostupné z: https://www.czso.cz/csu/czso/klasifikace_ekonomickych_cinnosti_cz_nace [Cit.: 29. 01. 2021].

Danel, R. 2017. Podklady k otázkám k předmětu Analýza a projektování systémů pro ekonomy. [Online]. Dostupné z: https://homel.vsb.cz/ dan11/aps_eko/03 APS EKO - metody analyzy.pdf [cit.: 15. 01. 2021].

Davies, A, Fidler, D a Gorbis, M. 2011. Future work skills 2020. [Online]. Dostupné z: http://www.iftf.org/futureworkskills/ [cit: 17. 02. 2021].

Dixit, Vinayak V., Chand, S., Nair, a Divya J. 2016. Autonomous Vehicles: Disengagements, Accidents and Reaction Times. PLoS ONE, 11(12), s. 1-14. 
Dogan, E. R., Mohamed-Cherif; Deborne, R., Delhomme, P., Kemeny, A., a Perrin, J. 2017. Transition of control in a partially automated vehicle: Effects of anticipation and non-driving-related task involvement. Transportation Research: Part F., Part A. 46, s. 205-215.

Evropská komise. 2011. Bílá kniha - Plán jednotného evropského dopravního prostoru - vytvoření konkurenceschopného dopravního systému účinně využívajícího zdroje. Dostupné z: https://www.euroskop.cz/gallery/96/29006-evropsky_dopravni_prostor.pdf [cit.: 10. 01. 2021].

Evropská unie. 2006. Nařízení evropského parlamentu a rady (ES) č. 561/2006 ze dne 15. března 2006 o harmonizaci některých předpisů v sociální oblasti týkajících se silniční dopravy, o změně nařízení Rady (EHS) č. 3821/85 a (ES) č. 2135/98 a o zrušení nařízení Rady (EHS) č. 3820/85. EUR-Lex. Stávající konsolidované znění: 20/08/2020: Kapitola II. Dostupné z: https://eur-lex.europa.eu/legalcontent/CS/TXT/PDF/?uri=CELEX:02006R0561-20200820\&from=CS [cit.: 08. 03. 2021].

Evropská unie. 2019. Postoj Evropského parlamentu přijatý v prvním čtení dne 4. dubna 2019 k přijetí nařízení Evropského parlamentu a Rady (EU) .../..., kterým se mění nařízení (ES) č. 561/2006, pokud jde o minimální požadavky na maximální denní a týdenní dobu řízení, minimální přestávky v řízení a týdenní doby odpočinku, a nařízení (EU) č. 165/2014, pokud jde o určování polohy pomocí tachografů. EUR-Lex. Dostupné z: https://www.europarl.europa.eu/doceo/document/TC1-COD-2018-0390_CS.pdf [cit.: 05. 02. 2021].

Eriksson, A., Banks, V. A. a Stanton, N. A. 2017. Transition to manual: Comparing simulator with on-road control transitions. Accident Analysis \& Prevention, 102C, s. 227-234.

Favarò, F. M., Nader, N., Eurich, Sky O., Tripp, M., a Varadaraju, N. 2017. Examining accident reports involving autonomous vehicles in California. PLOS ONE, 12(9), s. 1-20.

FMCSA. 2020. Hours of Service of Drivers: Pronto.ai, Inc., Application for Exemption [Online]. Dostupné z: https://www.govinfo.gov/content/pkg/FR-2020-09-28/pdf/2020-21324.pdf [cit.: 05. 03. 2021].

Gold, C., Dambrock, D., Lorenz, L. a Bengler, K. 2013. „Take over!” How long does it take to get the driver back into the loop? Sage Journals, 57(1), s. 1938-1942.

Goodall, W., Dovey, T., Bomstein, J. a Bonthron, B. 2017. The Rise for Mobility as a Service. Deloitte Review. 20.

Güney, A. 2014. Role of Technology in Accouting and E-accounting. Procedia-Social and Behavioral Sciences, 152(7), s. 852-855.

Hecht, T., Darlagiannis, E., Bengler, K. 2020. Non-driving Related Activities in Automated Driving - An Online Survey Investigating User Needs. Human Systems Engineering and Design II, s. 182-188.

Kockelman, K., Bansal, P., Boyles S. D., Bujanovic P., Choudhary, T., Clements, L., Domnenko, G., Helsel, J., Hutchinson, R., Levin, M., Li, J., Li, T., Loftus-Otway, L., Nichols, A., Simoni, M., Stewart, D., Avery, P. a Fagnant, D. 2016. Implications of Connected and Automated Vehicles on the Safety and Operations of Roadway Networks: A Final Report. [Online]. Dostupné z: https://library.ctr.utexas.edu/ctrpublications/0-6849-1.pdf [cit.: 10. 01. 2021].

Lazarus, J., Shaheen, S., Young, S. E., Fagnant, D., Voege, T., Baumgardner, W., Fishelson, J. a Lott J. S. 2018. Shared Automated Mobility and Public Transport. Road Vehicle Automation 4, s. 141-161.

Litman, T. 2020. Autonomous Vehicle Implementation Predictions Implications for Transport Planning. Victoria Transport Policy Institute. Dostupné z: https://www.vtpi.org/avip.pdf [cit.: 08. 01. 2021].

Merat, N., Jamson, A., Hamish, L., Frank C. H., Daly, M. a Carsten, O. M. J. 2014. Transition to manual: Driver behaviour when resuming control from a highly automated vehicle. Transportation Research: Part F, Part B, (27), s. 274-282.

Ministerstvo práce a sociálních věcí ČR (C) 2021. Centrální databáze kompetencí [Online]. Dostupné z: https://cdk.nsp.cz/ [cit.: 18. 01. 2021].

Petermann-Stock, I., a Rhede, J. 2013. Intelligente Strategien fuer nutzerzentrierte MMI Konzepte im urbanen Raum. Düsseldorf: VDI Verlag GmbH. 
SAE International. 2018. Taxonomy and Definitions for Terms Related to Driving Automation Systems for On-Road Motor Vehicles. J3016. [Online]. Dostupné z: https://www.sae.org/standards/content/j3016_201806/ [cit.: 02. 01. 2021].

Schömig, N. Hargutt, V. Neukum, A., Petermann-Stock, I. a Othersen, I. 2015. The Interaction Between Highly Automated Driving and the Development of Drowsiness. 6 th Internationa Conference on Applied Human Factors and Ergonomics (AHFE 2015). 26. - 30. července. Las Vegas, USA, s. 4242-4249.

Široký, J. et al. 2011. Tvoříme a publikujeme odborné texty: nejen pro ekonomy a manažery. Brno: Computer Press.

Taniguchi, E., Thompson, R.G. a Yamada, T. 2016. New opportunities and challenges for city logistics. Transportaion Research Procedia, 12, s. 5-13.

Wadud, Z. 2019. Driverless cars: how you'll use free time for work and rest - according to research. [Online]. Dostupné z: https://theconversation.com/driverless-cars-how-youll-use-free-time-for-workand-rest-according-to-research-113090 [cit.: 15. 02. 2021].

Weyer, J., Fink, R. D. a Adelt, F. 2015. Human-machine cooperation in smart cars. An empirical investigation of the loss-of-control thesis. Safety Science, 72, s. 199-208.

Witkowski, J. 2018. Electronic Freight Exchange and Logistic Platforms in Building of Supply Chains. CLC 2018 - Carpathian Logistics Congress. 3. - 5. prosince. Praha, Česká republika, s. 77-84.

World Economic Forum. 2020. The future of jobs report 2020. [Online]. Dostupné z: https://www.weforum.org/reports/the-future-of-jobs-report-2020 [cit.: 17. 02. 2021]. 